\title{
The amino acid transporter SLC7A5 confers a poor prognosis in the highly proliferative breast cancer subtypes and is a key therapeutic target in luminal B tumours
}

Rokaya El Ansari ${ }^{1}$, Madeleine L. Craze ${ }^{1}$, Islam Miligy ${ }^{1}$, Maria Diez-Rodriguez ${ }^{1}$, Christopher C. Nolan ${ }^{1}$, Ian O. Ellis ${ }^{1,2}$, Emad A. Rakha ${ }^{1,2}$ and Andrew R. Green ${ }^{1 *}$ (D)

\begin{abstract}
Background: Breast cancer (BC) is a heterogeneous disease characterised by variant biology and patient outcome. The amino acid transporter, SLC7A5, plays a role in BC although its impact on patient outcome in different $B C$ subtypes remains to be validated. This study aimed to determine whether the clinicopathological and prognostic value of SLC7A5 is different within the molecular classes of BC.

Methods: SLC7A5 was assessed at the genomic level, using Molecular Taxonomy of Breast Cancer International Consortium (METABRIC) data $(n=1980)$, and proteomic level, using immunohistochemical analysis and tissue microarray (TMA) ( $n=2664 ; 1110$ training and 1554 validation sets) in well-characterised primary BC cohorts. SLC7A5 expression correlated with clinicopathological and biological parameters, molecular subtypes and patient outcome.

Results: SLC7A5 mRNA and protein expression were strongly correlated with larger tumour size and higher grade. High expression was observed in triple negative (TN), human epidermal growth factor receptor 2 $($ HER2)+, and luminal B subtypes. SLC7A5 mRNA and protein expression was significantly associated with the expression of the key regulator of tumour cell metabolism, c-MYC, specifically in luminal B tumours only $(p=$ 0.001). High expression of SLC7A5 mRNA and protein was associated with poor patient outcome $(p<0.001)$ but only in the highly proliferative oestrogen receptor $(E R)+$ / luminal $B(p=0.007)$ and HER2+ classes of BC $(p=0.03)$. In multivariate analysis, SLC7A5 protein was an independent risk factor for shorter breast-cancerspecific survival only in ER+ high-proliferation tumours ( $p=0.02$ ).
\end{abstract}

Conclusions: SLC7A5 appears to play a role in the aggressive highly proliferative ER+ subtype driven by MYC and could act as a potential therapeutic target. Functional assessment is necessary to reveal the specific role played by this transporter in the ER+ highly proliferative subclass and HER2+ subclass of BC.

Keywords: SLC7A5, Breast cancer, Prognosis

\footnotetext{
* Correspondence: andrew.green@nottingham.ac.uk

${ }^{1}$ Academic Pathology, Division of Cancer and Stem Cells, School of Medicine,

University of Nottingham, Nottingham City Hospital, Hucknall Road,

Nottingham NG5 1PB, UK

Full list of author information is available at the end of the article
} 


\section{Background}

Altered metabolic pathways have been readily accepted as part of the revised hallmarks of cancer where cancer cells are able to regulate their metabolism to provide energy and cellular building blocks required for their unremitting proliferation [1]. Many cancer cells are highly reliant on amino acids for their growth, not only because they are a nitrogen donor for the synthesis of nucleotides and other amino acids, but also because they activate mammalian target of rapamycin complex1 (mTORC1) through nutrient signalling pathways which in turn regulates protein translation and cell growth $[2,3]$. There is also increasing evidence that oncogenes and/or tumour-suppressor genes can reprogramme tumour cell metabolism including the direct regulation of the amino acid transporter, solute carrier family 7 member 5 (SLC7A5), by the oncogene $M Y C$ $[4,5]$ and the regulation of expression of the glutamine transporter, SLC1A5, by the tumour suppressor retinoblastoma $(R b)[6]$.

SLC7A5 is a sodium-independent transporter and acts as an amino acid exchanger by transporting large neutral amino acids such as leucine, phenylalanine and tryptophan by exchange with intracellular glutamine [7]. It therefore functions in supplying amino acids to cancer cells and maintaining intra-cellular leucine, which is considered a master regulator of the mTORC1 signalling pathway [8-10]. For functional expression on the plasma membrane, SLC7A5 must heterodimerise with the heavy chain of SLC3A2 [7, 11].

It has been reported that SLC7A5 is highly expressed in a variety of cancers including oesophageal carcinoma [12], oral cancer [13] and lung adenocarcinoma [14]. SLC7A5 is co-expressed with the glutamine transporter, SLC1A5, in many cancers suggesting a functional coupling of these transporters in supporting tumour progression [15]. In this study, we aimed to assess SLC7A5 gene copy number and mRNA expression, alongside protein expression in large and well-characterised annotated cohorts of $\mathrm{BC}$ to determine its biological, clinicopathological and prognostic value in the different $\mathrm{BC}$ molecular classes with particular interest in the highly proliferative aggressive subgroups.

\section{Methods}

\section{SLC7A5 copy number and gene expression}

A cohort of 1980 BC tumours in the Molecular Taxonomy of Breast Cancer International Consortium (METABRIC) [16] was used to evaluate SLC7A5 gene copy number aberrations (CNA) and gene expression. DNA/RNA was isolated from fresh frozen samples and genomic and transcriptional profiling was obtained using the Affymetrix SNP 6.0 and Illumina HT-12v3 platforms respectively. CNA were considered at the gene level by segments and the Šidák correction [17] was applied for multiple testing. Gene expression data were pre-processed and normalised as described previously [16]. In this cohort, patients included were oestrogen receptor (ER)-positive $(\mathrm{ER}+)$ and/or lymph node (LN)-negative (LN-) and did not receive adjuvant chemotherapy, whereas ER- and $\mathrm{LN}+$ patients received adjuvant treatment. X-tile (version 3.6.1, Yale University, USA) was applied to dichotomise SLC7A5 mRNA expression, based on prediction of breast-cancerspecific survival (BCSS). The association between the SLC7A5 mRNA expression and clinicopathological parameters, molecular subtypes, and patient outcome was investigated. The online dataset, Breast Cancer Gene Expression Miner v4.0 (http://bcgenex.centregauducheau.fr) and breast cancer data from The Cancer Genome Atlas (TCGA) [18] were used for external validation of SLC7A5 copy number/or mRNA expression.

\section{Patients and tumours}

This study evaluated well-characterised cohorts of patients with early-stage primary operable invasive $\mathrm{BC}$, who presented aged $\leq 70$ years. Patients in the discovery set $(n=1110)$ presented at Nottingham City Hospital between 1989 and 1998, while the validation set $(n=$ 1554) includes patients who were presented between 1998 and 2006. Patient management was uniform and based on tumour characteristics by Nottingham Prognostic Index (NPI) and hormone receptor status. Patients within the NPI excellent prognostic group (score $\leq 3.4$ ) received no adjuvant therapy, but those patients with NPI $>3.4$ received tamoxifen if ER-positive $( \pm$ goserelin (Zoladex) in case the patients were premenopausal). Conversely, classical cyclophosphamide, methotrexate and 5-flurouracil (CMF) were used if the patients were ER-negative and fit enough to receive chemotherapy. None of the patients in this study received neoadjuvant therapy. Clinical history, tumour characteristics and information on therapy and outcomes are prospectively maintained. Outcome data included development and time to distant metastasis (DM) and breast-cancerspecific survival (BCSS). There was no difference in the distribution of clinicopathological parameters between the discovery and validation cohorts or the METABRIC series of patients (all correlation coefficients $\geq 0.91$, all $p$ $<0.0001$ ) (Additional file 1: Table S1).

\section{Western blotting}

The antibody specificity of anti-SLC7A5 (EPR17573, Abcam, UK) was validated using western blotting in human embryonic kidney (HEK) 293 T over expression lysate (Origene Technologies, Rockville, MD, USA) and MDA-MB-175 (luminal B-like), T47D and MCF7 (luminal A) [19] breast cancer lysate (American Type Culture Collection; Rockville, MD, USA). A dilution of 

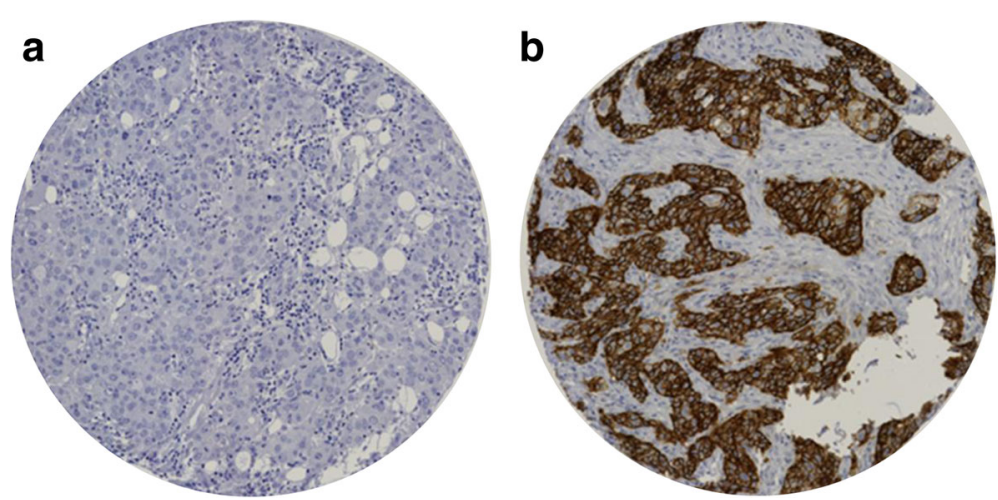

Fig. 1 SLC7A5 protein expression in invasive breast cancer cores. a Negative immunohistochemical (IHC) expression. b Positive IHC expression

1:200 of the primary antibody and 1:1000 HRPconjugated (Dako) secondary antibodies were applied: 5\% milk /PBS-Tween (0.1\%) (Marvel Original Dried Skimmed Milk, Premier Food Groups Ltd., UK) was used for blocking. Mouse monoclonal anti- $\beta$-actin primary antibody was used as a marker of endogenously expressed control. SLC7A5 bands were visualised using enhanced chemiluminescence (ECL) showing a single specific band at the correct predicted size $(40 \mathrm{kDa})$ for the SLC7A5 protein.

\section{Tissue arrays and immunohistochemical analysis}

The discovery set $(n=1110)$ were arrayed as previously described using a single $0.6-\mathrm{mm}$ core sampled from the periphery of each invasive tumour [20]. The validation set ( $n=1554)$ were similarly arrayed using a tissue microarray (TMA) GrandMaster (3D Histech). Immunohistochemical (IHC) staining was performed on 4- $\mu$ m TMA sections using the Novolink polymer detection system (Leica Biosystems, RE7150-K). Briefly, tissue slides were deparaffinised with xylene and rehydrated through three changes of alcohol. Heat-induced antigen epitope retrieval was performed in citrate buffer ( $\mathrm{pH}$ 6.0) for 20 min using a microwave oven (Whirpool JT359 Jet Chef 1000 W). Endogenous peroxidase activity was blocked by peroxidase block for $5 \mathrm{~min}$. Slides were washed with Tris-buffered saline (TBS, $\mathrm{pH}$ 7.6), followed by application of protein block for $5 \mathrm{~min}$. Following another TBS wash, sections were incubated with the primary SLC7A5 antibody diluted at 1:50 in Leica antibody diluent (RE AR9352, Lieca, Biosysytems, UK) overnight at $4{ }^{\circ} \mathrm{C}$. Slides were washed with TBS followed by incubation with post primary block for $30 \mathrm{~min}$ followed by a TBS wash. Novolink polymer was applied for 30 min: 3,3'-diaminobenzidine (DAB) chromogen was applied for $5 \mathrm{~min}$. Slides were counterstained with Novolink haematoxylin for 6 min, dehydrated and coverslipped.

Stained TMA sections were scored using high resolution digital images (NanoZoomer; Hamamatsu
Photonics, Welwyn Garden City, UK), at $\times 20$ magnification. Evaluation of staining for SLC7A5 was based on a semi-quantitative assessment of digital images of the cores using a modified histochemical score $(\mathrm{H}$ score) which includes an assessment of both the intensity and the percentage of stained cells [21]. Staining intensity was assessed as follows: 0 , negative; 1 , weak; 2 , medium; 3 , strong, and the percentage of the positively stained tumour cells was estimated subjectively. The final $\mathrm{H}$-score was calculated by multiplying the percentage of positive cells $(0-100)$ by the intensity $(0-3)$, producing a total range of $0-300$. Dichotomisation of protein expression in predicting BCSS was determined using $\mathrm{x}$-tile software.

Immunhistochemical staining and dichotomisation of the other biomarkers included in this study were as per previous publications [20, 22-30]. ER and

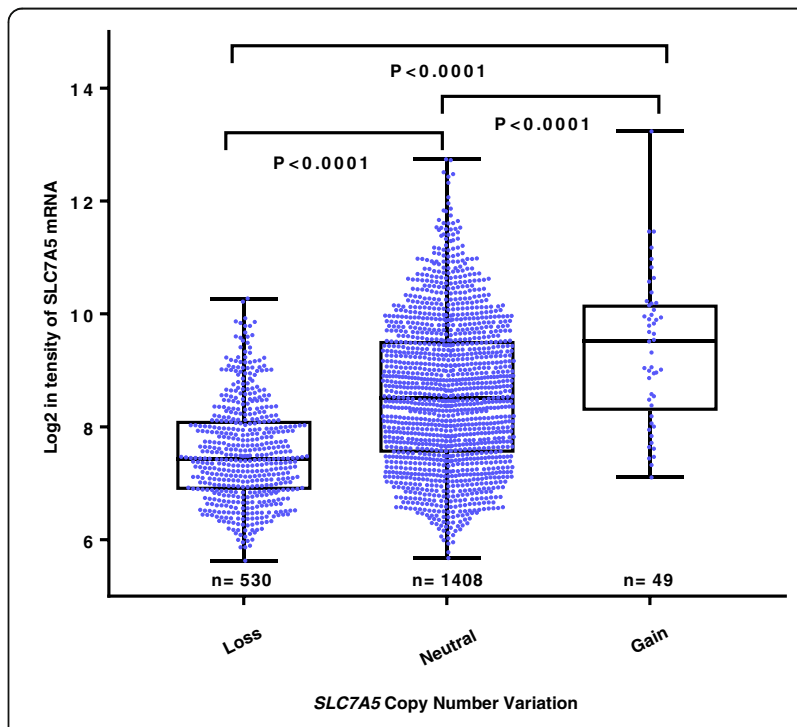

Fig. 2 SLC7A5 copy number aberrations and relationship with mRNA expression in the Molecular Taxonomy of Breast Cancer International Consortium (METABRIC) cohort using one-way analysis of variance and the post-hoc Tukey test 
Table 1 Clinicopathological associations of SLC7A5 protein expression in the discovery and validation breast cancer series

\begin{tabular}{|c|c|c|c|c|c|c|c|c|c|c|}
\hline \multicolumn{11}{|l|}{ SLC7A5 protein } \\
\hline \multicolumn{6}{|l|}{ Discovery set } & \multicolumn{5}{|l|}{ Validation set } \\
\hline & Number (\%) & \multicolumn{2}{|l|}{ Mean } & $p$ value & $\begin{array}{l}\text { Adjusted } \\
p \text { value }\end{array}$ & Number (\%) & \multicolumn{2}{|l|}{ Mean } & $p$ value & $\begin{array}{l}\text { Adjusted } \\
p \text { value }\end{array}$ \\
\hline \multicolumn{11}{|l|}{ Patient's age (years) } \\
\hline$\geq 50$ & $395(36)$ & 582.20 & & \multirow[t]{2}{*}{0.003} & \multirow[t]{2}{*}{0.018} & $469(30)$ & 859.46 & & \multirow{2}{*}{$7_{-12}^{7.0} \times 10$} & \multirow[t]{2}{*}{$<0.0001$} \\
\hline$<50$ & $714(64)$ & 539.95 & & & & $1070(70)$ & 730.79 & & & \\
\hline \multicolumn{11}{|l|}{ Tumour size } \\
\hline$\geq 2.0 \mathrm{~cm}$ & $532(48)$ & 521.22 & & \multirow[t]{2}{*}{0.000002} & \multirow[t]{2}{*}{$<0.0001$} & $939(61)$ & 729.47 & & \multirow[t]{2}{*}{$6.5 \times 10^{-9}$} & \multirow[t]{2}{*}{$<0.0001$} \\
\hline$<2.0 \mathrm{~cm}$ & $577(52)$ & 586.14 & & & & $599(39)$ & 832.24 & & & \\
\hline \multicolumn{11}{|c|}{ Lympho-vascular invasion } \\
\hline Negative & $722(65)$ & 545.17 & & \multirow[t]{2}{*}{0.138} & \multirow[t]{2}{*}{0.55} & $1086(71)$ & 743.95 & & \multirow[t]{2}{*}{0.000007} & \multirow[t]{2}{*}{$<0.0001$} \\
\hline Positive & $382(35)$ & 566.35 & & & & $451(29)$ & 829.31 & & & \\
\hline \multicolumn{11}{|c|}{ Site of distant metastasis } \\
\hline \multicolumn{11}{|l|}{ Brain } \\
\hline No & $1044(94)$ & 546.62 & & 0.0001 & 0.0008 & $\mathrm{~N} / \mathrm{A}$ & & & & \\
\hline Yes & $61(6)$ & 662.27 & & & & & & & & \\
\hline Lung & & & & & & & & & & \\
\hline No & $1003(91)$ & 547.12 & & 0.007 & 0.04 & N/A & & & & \\
\hline Yes & $102(9)$ & 610.80 & & & & & & & & \\
\hline Bone & & & & & & & & & & \\
\hline No & $876(79)$ & 554.57 & & 0.651 & 1.30 & N/A & & & & \\
\hline Yes & $229(21)$ & 547.00 & & & & & & & & \\
\hline Liver & & & & & & & & & & \\
\hline No & $949(86)$ & 551.43 & & 0.568 & 1.70 & N/A & & & & \\
\hline Yes & $156(14)$ & 562.57 & & & & & & & & \\
\hline & Number (\%) & Mean & $x^{2}$ & $p$ value & $\begin{array}{l}\text { Adjusted } p \\
\text { value }\end{array}$ & Number (\%) & Mean & $x^{2}$ & $p$ value & $\begin{array}{l}\text { Adjusted } p \\
\text { value }\end{array}$ \\
\hline Tumour grade & & & & & & & & & & \\
\hline 1 & $190(17)$ & 450.77 & 171.5 & $\underset{-38}{5.6} \times 10$ & $<0.0001$ & $231(15)$ & 585.30 & 723.48 & $7.7 \times 10$ & $<0.0001$ \\
\hline 2 & $366(33)$ & 473.19 & & & & $622(40)$ & 647.46 & & & \\
\hline 3 & $550(50)$ & 642.43 & & & & $685(45)$ & 942.43 & & & \\
\hline Lymph node stage & & & & & & & & & & \\
\hline 1 & $674(61)$ & 542.19 & 4.811 & 0.09 & 0.45 & $955(62)$ & 754.30 & 12.56 & 0.002 & 0.004 \\
\hline 2 & $341(31)$ & 574.98 & & & & $428(28)$ & 767.94 & & & \\
\hline 3 & $91(8)$ & 556.75 & & & & $153(10)$ & 858.69 & & & \\
\hline Nottingham Prognc & & & & & & & & & & \\
\hline Good & $332(30)$ & 458.21 & 102.4 & $5.6 \times 10$ & $<0.0001$ & $521(34)$ & 620.66 & 156.60 & $9.8 \times 10$ & $<0.0001$ \\
\hline Moderate & $593(53)$ & 578.27 & & & & $768(50)$ & 828.08 & & & \\
\hline Poor & $184(17)$ & 654.64 & & & & $246(16)$ & 892.49 & & & \\
\hline IHC subtypes & & & & & & & & & & \\
\hline $\begin{array}{l}\text { ER+/HER2- low } \\
\text { proliferation }\end{array}$ & $250(27)$ & 391.92 & 178.4 & $\begin{array}{l}1.8 \times 10 \\
-38\end{array}$ & $<0.0001$ & N/A & & & & \\
\hline $\begin{array}{l}\text { ER+/HER2- high } \\
\text { proliferation }\end{array}$ & $351(38)$ & 419.54 & & & & & & & & \\
\hline Triple negative & $191(20)$ & 617.95 & & & & & & & & \\
\hline HER2+ & $143(15)$ & 519.69 & & & & & & & & \\
\hline
\end{tabular}


Table 1 Clinicopathological associations of SLC7A5 protein expression in the discovery and validation breast cancer series (Continued)

\begin{tabular}{|c|c|c|c|c|c|c|c|c|c|c|}
\hline \multicolumn{11}{|l|}{ SLC7A5 protein } \\
\hline \multicolumn{6}{|l|}{ Discovery set } & \multicolumn{5}{|l|}{ Validation set } \\
\hline & Number (\%) & Mean & & $p$ value & $\begin{array}{l}\text { Adjusted } \\
p \text { value }\end{array}$ & Number (\%) & Mean & & $p$ value & $\begin{array}{l}\text { Adjusted } \\
p \text { value }\end{array}$ \\
\hline \multicolumn{11}{|l|}{ Histological type } \\
\hline Ductal (including mixed) & $922(83)$ & 563.83 & 69.05 & $3.5 \times 10$ & $<0.0001$ & $1335(87)$ & 782.19 & 77.07 & $7.2 \times 10$ & $<0.0001$ \\
\hline Lobular & $101(9)$ & 454.17 & & & & $120(8)$ & 584.17 & & & \\
\hline Medullary & $26(2)$ & 832.02 & & & & $13(0.8)$ & 1257.27 & & & \\
\hline Miscellaneous & $7(0.6)$ & 440.50 & & & & $9(0.6)$ & 1037.78 & & & \\
\hline Special type & $53(5.4)$ & 472.75 & & & & $57(3.6)$ & 655.12 & & & \\
\hline
\end{tabular}

IHC immunohistochemical analysis, ER oestrogen receptor, HER2 human epidermal growth factor receptor 2, NA Not applicable

$p$ value in bold in these tables means statistically significant associations

progesterone receptor $(\mathrm{PgR})$ positivity was defined as $\geq 1 \%$ staining. Immunoreactivity of HER2 in TMA cores was scored using standard HercepTest guidelines (Dako). Chromogenic in situ hybridisation (CISH) was used to quantify HER2 gene amplification in borderline cases using the HER2 FISH pharmDx ${ }^{\text {тм }}$ plus HER2 CISH pharmDx ${ }^{\mathrm{TM}}$ kit (Dako) and was assessed according to the American Society of Clinical Oncology guidelines. BC molecular subtypes were defined based on tumour IHC profile and the ElstonEllis [31] mitotic score as: ER+/HER2- low proliferation (mitotic score 1), ER+/HER2- high proliferation (mitotic score 2 and 3); HER2-positive class: HER2+ regardless of ER status; triple negative: ER-, PgR- and HER2- [32]. Basal-like phenotype was defined as tumours expressing cytokeratin (Ck) 5/6, and/or Ck14 and/or Ck17.

\section{Statistical analysis}

Statistical analysis was performed using SPSS 22.0 statistical software (SPSS Inc., Chicago, IL, USA). Spearman's correlation coefficient was calcualted to examine the association between continuous variables. The chi-square test was performed to analyse relationships between categorical variables. For the continuous variables, differences between three or more groups were assessed using one-way analysis of variance (ANOVA) with the post-hoc Tukey multiple comparison test (for normally distributed data) or Kruskal-Wallis test (for non-normal distribution). Differences between two groups were assessed using the $t$ test (normally distributed data) or Mann-Whitney test (non-normal distribution). Survival curves were analysed by the Kaplan-Meier and log rank test. Cox's proportional hazard method was performed for multivariate analysis to identify the independent prognostic/predictive factors. The $p$ values were adjusted for multiple testing using the Bonferroni correction. A $p$ value $<0.05$ was considered significant. The study endpoints were 10-year BCSS or distant metastasis-free survival (DMFS).

\section{Results \\ SLC7A5 genomic profiling}

SLC7A5 was amplified in $0.3 \%$ and $0.6 \%$ of BC cases in the METABRIC and TCGA datasets, respectively, while deletion (deep and shallow) was detected in $56 \%$ and $68 \%$ of cases in the same cohorts respectively. Point mutations in SLC7A5 were extremely rare, where TCGA data reported just one case with a missense mutation (Additional file 2: Figure S4A) [33, 34]. SLC7A5 is situated on chromosome 16 (16q24.2); all the annotated genes, which were located on $16 \mathrm{q}$ [35] were selected to determine their $\mathrm{CNV}$ in relation to SLC7A5 and assess whether these aberrations were locus-specific or involved large chromosomal segments. There was significant positive correlation between SLC7A5 deletion and the deletion of all genes $(p<0.001$, Additional file 3: Table S2) in both the METABRIC and TCGA data. However, amplification of three genes (FANCA, CBFA2T3 and CDT1) showed significant association with the amplified SLC7A5 ( $p$ $\leq 0.03$, data not shown) in the afore-mentioned datasets together.

\section{SLC7A5 expression in breast cancer}

SLC7A5 protein expression was observed, predominantly in the membrane of invasive breast cancer cells, with expression levels varying from absent to high (Fig. 1b and c). The distribution of the SLC7A5 protein expression was unimodal and left-skewed. The SLC7A5 mRNA expression had a normal distribution. Expression of SLC7A5 mRNA and protein were dichotomised using cut points derived from prediction of patient survival using X-tile (https://medicine.yale.edu/lab/rimm/ research/software.aspx; Yale University). Positive 

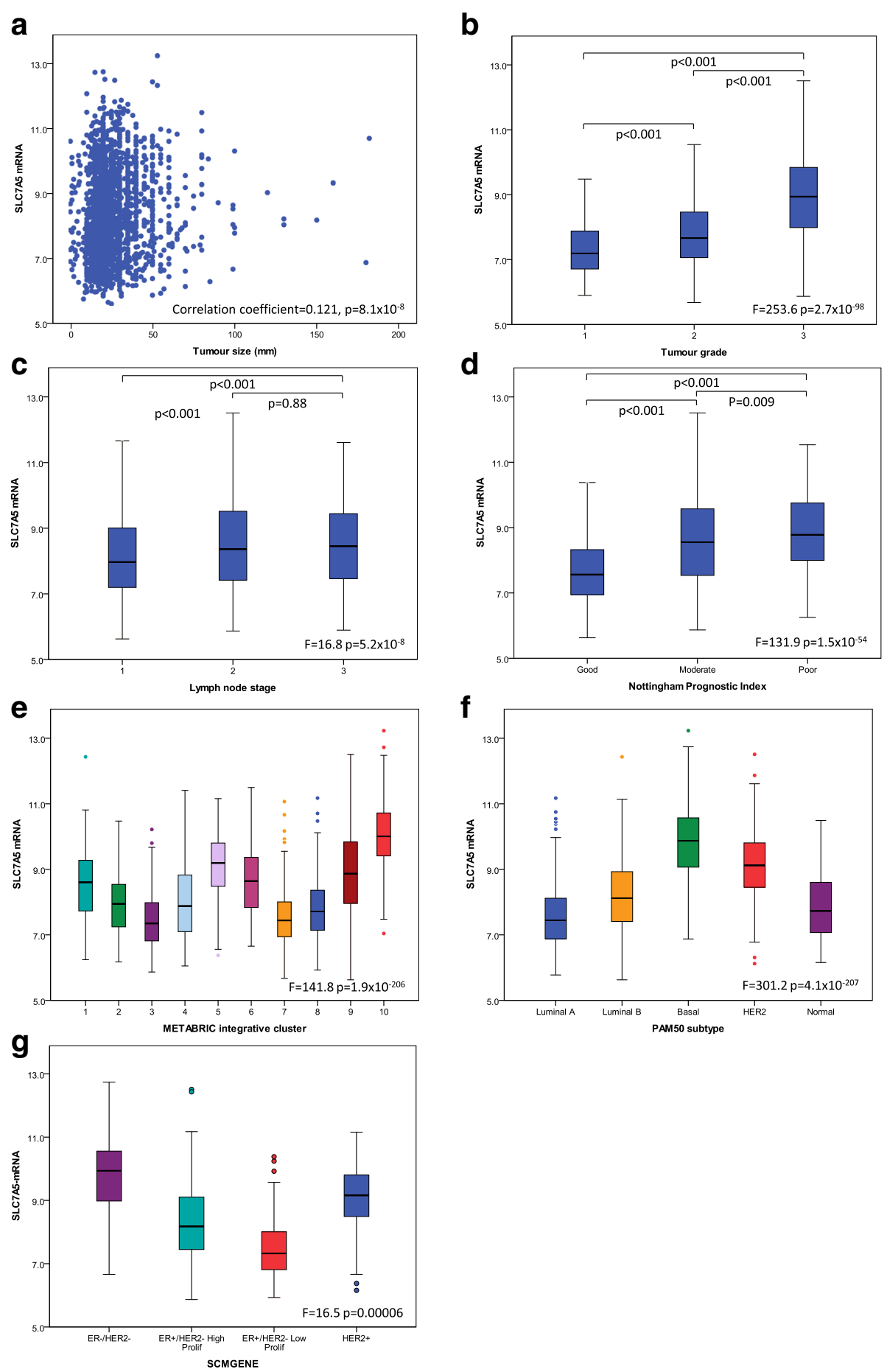

Fig. 3 SLC7A5 mRNA expression and its association with clinicopathological parameters and molecular subtypes. a SLC7A5 and tumour size. b SLC7A5 and tumour grade. c SLC7A5 and lymph node stage. d SLC7A5 and Nottingham Prognostic Index. e SLC7A5 and Molecular Taxonomy of Breast Cancer International Consortium (METABRIC) integrative clusters. f SLC7A5 and prediction analysis of microarray 50 (PAM50) subtypes, $\mathbf{g}$ SLC7A5 and SMCGENE subtypes in the METABRIC cohort using one-way analysis of variance with the post-hoc Tukey test

SLC7A5 expression (>15 H-score) was observed in 191/ $1110(17 \%)$ and $268 / 1554$ (17\%) of cases in the discovery and validation sets, respectively, while high SLC7A5 mRNA expression (log2 intensity $>8$ ) was observed in
$1019 / 1923$ (53\%) of the METABRIC breast cancer cases. A total of $49 / 1980$ (2.4\%) of cases had a copy number (CN) gain of SLC7A5 and 530/1980 (26.7\%) a $\mathrm{CN}$ loss. Significant association was observed between 
Table 2 Copy number aberrations of SLC7A5 in the Molecular Taxonomy of Breast Cancer International Consortium (METABRIC) breast cancer series and their association with clinicopathological parameters, MYC copy number aberrations and breast cancer subtypes

\begin{tabular}{|c|c|c|c|c|c|c|c|c|}
\hline \multicolumn{9}{|c|}{ SLC7A5 copy number } \\
\hline \multicolumn{4}{|l|}{ Gain } & \multicolumn{5}{|l|}{ Loss } \\
\hline & $\begin{array}{l}\text { No, } \\
\text { number (\%) }\end{array}$ & $\begin{array}{l}\text { Yes, } \\
\text { number (\%) }\end{array}$ & $x^{2}$ ( $p$ value) & Adjusted $p$ value & $\begin{array}{l}\text { No, } \\
\text { number (\%) }\end{array}$ & $\begin{array}{l}\text { Yes, } \\
\text { number (\%) }\end{array}$ & $x^{2}$ ( $p$ value) & Adjusted $p$ value \\
\hline \multicolumn{9}{|l|}{ Age (years) } \\
\hline$\geq 50$ & $1520(97.7)$ & $36(2.3)$ & $0.405(0.524)$ & 1.572 & $1098(70.6)$ & $458(29.4)$ & $27.479\left(1.5 \times 10^{-7}\right)$ & $<0.0001$ \\
\hline$<50$ & $372(97.1)$ & $11(2.9)$ & & & $321(83.8)$ & $62(16.2)$ & & \\
\hline \multicolumn{9}{|l|}{ Tumour size } \\
\hline$\geq 2.0 \mathrm{~cm}$ & $1291(97.0)$ & $40(3.0)$ & $5.226(0.022)$ & 0.132 & $976(73.3)$ & $355(26.7)$ & $0.094(0.759)$ & 0.282 \\
\hline $2.0 \mathrm{~cm}$ & $614(98.7)$ & $8(1.3)$ & & & $452(72.7)$ & $170(27.3)$ & & \\
\hline \multicolumn{9}{|l|}{ Tumour grade } \\
\hline 1 & $170(100.0)$ & $0(0.0)$ & $10.154(0.006)$ & 0.042 & 99 (58.2) & $71(41.8)$ & $107.364 .8 \times 10^{-24}$ & $<0.0001$ \\
\hline 2 & $756(98.2)$ & $14(1.8)$ & & & $495(64.3)$ & $275(35.7)$ & & \\
\hline 3 & $918(96.4)$ & $34(3.6)$ & & & $799(83.9)$ & $153(16.1)$ & & \\
\hline \multicolumn{9}{|c|}{ Lymph node stage } \\
\hline 1 & $1012(97.8)$ & $23(2.2)$ & $0.474(0.789)$ & 1.578 & $726(70.1)$ & $309(29.9)$ & $10.425(0.005)$ & 0.02 \\
\hline 2 & $606(97.4)$ & $16(2.6)$ & & & $480(77.2)$ & $142(22.8)$ & & \\
\hline 3 & 307 (97.2) & $9(2.8)$ & & & $237(75.0)$ & $79(25.0)$ & & \\
\hline \multicolumn{9}{|c|}{ Nottingham Prognostic Index } \\
\hline Good & $668(98.2)$ & $12(1.8)$ & $2.602(0.272)$ & 0.080 & $418(61.5)$ & $262(38.5)$ & $76.132\left(2.9 \times 10^{-17}\right)$ & $<0.0001$ \\
\hline Moderate & $1071(97.3)$ & $30(2.7)$ & & & $864(78.5)$ & $237(21.5)$ & & \\
\hline Poor & $192(96.5)$ & $7(3.5)$ & & & $168(84.4)$ & $31(15.6)$ & & \\
\hline \multicolumn{9}{|l|}{ Histological type } \\
\hline Ductal & $1500(97.2)$ & $44(2.8)$ & $6.880(0.230)$ & 1.150 & $1154(74.7)$ & $390(25.3)$ & $29.544(0.00001)$ & 0.0001 \\
\hline Lobular & $145(98.6)$ & $2(1.4)$ & & & $88(59.9)$ & $59(40.1)$ & & \\
\hline Medullary & $30(93.8)$ & $2(6.3)$ & & & $30(93.8)$ & $2(6.2)$ & & \\
\hline Miscellaneous & $12(100.0)$ & $0(0.0)$ & & & $9(75.0)$ & $3(25.0)$ & & \\
\hline Special type & $113(100.0)$ & $0(0.0)$ & & & $74(66.8)$ & $39(33.2)$ & & \\
\hline \multicolumn{9}{|l|}{ PAM50 subtype } \\
\hline Luminal A & $710(98.9)$ & $8(1.1)$ & $40.515\left(3.3 \times 10^{-8}\right)$ & $<0.0001$ & $423(58.9)$ & $295(41.1)$ & $248.3\left(1.4 \times 10^{-52}\right)$ & $<0.0001$ \\
\hline Luminal B & $477(97.7)$ & $11(2.3)$ & & & $312(63.9)$ & $176(36.1)$ & & \\
\hline Basal & $305(92.7)$ & $24(7.3)$ & & & $319(97.0)$ & $10(3.0)$ & & \\
\hline HER2+ & 235 (97.9) & $5(2.1)$ & & & $219(91.3)$ & $21(8.7)$ & & \\
\hline Normal-like & $198(99.5)$ & $1(0.5)$ & & & $172(11.9)$ & $27(5.1)$ & & \\
\hline \multicolumn{9}{|l|}{ MYC gain } \\
\hline No & $1228(98.9)$ & $14(1.1)$ & $25.0\left(5.5 \times 10^{-7}\right)$ & $<0.0001$ & $1446(73.3)$ & $528(26.7)$ & $0.132(0.716)$ & 1.432 \\
\hline Yes & 703 (95.3) & $35(4.7)$ & & & $4(66.7)$ & $2(33.3)$ & & \\
\hline
\end{tabular}

PAM50 prediction analysis of microarray, HER2 human epidermal growth factor receptor 2

$p$ value in bold in these tables means statistically significant associations

SLC7A5 copy number variation (CNV) and SLC7A5 mRNA expression $(p<0.001$, Fig. 2$)$.

\section{SLC7A5 and clinicopathological parameters}

Table 1 summarises the associations between SLC7A5 protein expression including larger tumour size, high tumour grade, and poor Nottingham Prognostic Index (NPI) (all $p<0.001$ ). Regarding BC metastatic sites, high SLC7A5 protein levels were associated with the development of distant metastases (DM) in the brain $(p<0.001)$ and lung $(p=0.04)$, while there was no association with development of DM in the bone or liver. 
High SLC7A5 mRNA expression was significantly associated with larger tumour size (Fig. 3a, $p<0.001$ ), higher grade (Fig. $3 \mathrm{~b}, p<0.001$ ), positive nodal metastasis (Fig. 3c, p< 0.001) and poor NPI (Fig. 3d, $p<$ 0.001). Both SLC7A5 mRNA and SLC7A5 protein were associated with medullary-like tumours. Where data were available, these associations were confirmed using the Breast Cancer Gene-Expression Miner v4.0 (Additional file 4: Figure S1A, B) and the TCGA data (Additional file 2: Figure S4B). In addition SLC7A5 copy number loss was significantly associated with good prognostic parameters including, lower grade and good NPI (Table 2, $p<0.001$ ). There was positive association between SLC7A5 copy number gain and $M Y C$ gain $(p<0.001$, Table 2$)$.

\section{SLC7A5 expression in molecular BC subtypes}

SLC7A5 protein expression was associated with negative hormone receptor status and HER2+ tumours (all $p \leq 0.002$, Table 3 ) and it was highly expressed in triple negative $(\mathrm{TN})$ and basal-like phenotype malignancies compared to non-TN and non-basal-like tumours $(p<$ 0.001, Table 3). Similarly, high expression of SLC7A5 mRNA was significantly associated with hormone receptor negative (ER- and PgR-) and HER2+ tumours (all $p<0.001$, Table 4). These results were in concordance with the findings of the Breast Cancer GeneExpression Miner v4.0 (Additional file 4: Figure S1CF) and TCGA data analysis (Additional file 2: Figure S4C-E).

When comparing the levels of SLC7A5 mRNA expression in the intrinsic (prediction analysis of microarray 50 (PAM50)) subtypes [36], high expression was observed in basal-like, HER2+ and lLuminal B tumours (Fig. 3f, $p$ $<0.001)$. Similarly, within the METABRIC integrative clusters, high SLC7A5 mRNA expression was associated with clusters 5 (ERBB2 amplified), 9 (luminal B subgroup) and 10 (TN/basal-like) $(p<0.001$, Fig. 3e). In the SCMGENE subtypes there was higher expression of SLC7A5 mRNA in the ER+/HER2- high proliferation class (luminal B) compared with the ER+/HER2- low proliferation class (luminal A) $(p<0.001$, Fig. 3g). Association between SLC7A5 mRNA and PAM50 subtypes was confirmed using the Breast Cancer Gene-Expression Miner v4.0 (Additional file 4: Figure S1G). There was lower expression of SLC7A5 protein in the lowproliferation tumours than in the other defined molecular subtypes subtypes $(p<0.001$, Table 1$)$.

At the gene level, there was a greater copy number gain of SLC7A5 $(p<0.001$, Table 2 in the basal-like

Table 3 Association of SLC7A5 protein expression and the expression of other molecular biomarkers in the discovery and validation sets

\begin{tabular}{|c|c|c|c|c|c|c|c|c|}
\hline \multicolumn{9}{|c|}{ SLC7A5 protein } \\
\hline \multicolumn{5}{|l|}{ Discovery set } & \multicolumn{4}{|l|}{ Validation set } \\
\hline & Number (\%) & Mean & $p$ value & Adjusted $p$ value & Number (\%) & Mean & $p$ value & Adjusted $p$ value \\
\hline \multicolumn{9}{|l|}{ ER } \\
\hline Negative & $270(25)$ & 722.20 & $3.2 \times 10^{-48}$ & $<0.0001$ & $300(19)$ & 1094.70 & $4.6 \times 10^{-76}$ & $<0.0001$ \\
\hline Positive & $827(75)$ & 492.45 & & & $1240(81)$ & 692.06 & & \\
\hline \multicolumn{9}{|l|}{$\mathrm{PgR}$} \\
\hline Negative & $435(41)$ & 619.12 & $8.8 \times 10^{-27}$ & $<0.0001$ & $612(42)$ & 855.53 & $1.3 \times 10^{-34}$ & $<0.0001$ \\
\hline Positive & $630(59)$ & 473.54 & & & $853(58)$ & 645.09 & & \\
\hline \multicolumn{9}{|l|}{ HER2 } \\
\hline Negative & $921(87)$ & 521.78 & 0.00004 & 0.0001 & 1337 (92) & 718.53 & 0.001 & 0.002 \\
\hline Positive & $143(13)$ & 601.54 & & & $116(8)$ & 824.67 & & \\
\hline \multicolumn{9}{|c|}{ Triple negative } \\
\hline No & $896(83)$ & 503.50 & $4.5 \times 10^{-35}$ & $<0.0001$ & $1286(83)$ & 696.76 & $1.5 \times 10^{-62}$ & $<0.0001$ \\
\hline Yes & $185(17)$ & 722.61 & & & $225(17)$ & 1094.6 & & \\
\hline \multicolumn{9}{|c|}{ Basal phenotype } \\
\hline No & $794(74)$ & 510.96 & $6.8 \times 10^{-13}$ & $<0.0001$ & N/A & & & \\
\hline Yes & $285(26)$ & 620.90 & & & & & & \\
\hline \multicolumn{9}{|l|}{ P53 protein } \\
\hline Negative & $760(72)$ & 499.14 & $4.1 \times 10^{-13}$ & $<0.0001$ & N/A & & & \\
\hline Positive & $298(28)$ & 606.92 & & & & & & \\
\hline
\end{tabular}

$E R$ oestrogen receptor, $P g R$ progesterone receptor, $H E R 2$ human epidermal growth factor receptor, NA not applicable $p$ value in bold in these tables means statistically significant associations 
Table 4 Association of SLC7A5 mRNA expression and the expression of other molecular biomarkers in the Molecular Taxonomy of Breast Cancer International Consortium (METABRIC) series

\begin{tabular}{|c|c|c|c|c|c|}
\hline \multicolumn{6}{|c|}{ SLC7A5 mRNA expression } \\
\hline & Number (\%) & Mean & $t$ test & $p$ value & Adjusted $p$ value \\
\hline \multicolumn{6}{|c|}{ Estrogen receptor } \\
\hline Negative & $474(24)$ & 9.543 & \multirow[t]{2}{*}{26.90} & \multirow[t]{2}{*}{$5.6 \times 10^{-113}$} & \multirow[t]{2}{*}{$<0.0001$} \\
\hline Positive & $1506(76)$ & 7.943 & & & \\
\hline \multicolumn{6}{|c|}{ Progesterone receptor } \\
\hline Negative & $940(47)$ & 8.862 & \multirow[t]{2}{*}{18.73} & \multirow[t]{2}{*}{$1.07 \times 10^{-71}$} & \multirow[t]{2}{*}{$<0.0001$} \\
\hline Positive & $1040(53)$ & 7.841 & & & \\
\hline \multicolumn{6}{|l|}{ HER2 } \\
\hline Negative & $1733(88)$ & 8.216 & \multirow[t]{2}{*}{-12.35} & \multirow[t]{2}{*}{$1.1 \times 10^{-29}$} & \multirow[t]{2}{*}{$<0.0001$} \\
\hline Positive & $247(12)$ & 9.095 & & & \\
\hline \multicolumn{6}{|c|}{ Triple negative (ER-, PR-, HER2-) } \\
\hline No & $1660(84)$ & 8.065 & \multirow[t]{2}{*}{-22.12} & \multirow[t]{2}{*}{$1.9 \times 10^{-73}$} & \multirow[t]{2}{*}{$<0.0001$} \\
\hline Yes & $320(16)$ & 9.676 & & & \\
\hline \multicolumn{6}{|c|}{ Basal phenotype } \\
\hline No & $1645(83)$ & 8.036 & \multirow[t]{2}{*}{-25.70} & \multirow[t]{2}{*}{$1.5 \times 10^{-91}$} & \multirow[t]{2}{*}{$<0.0001$} \\
\hline Yes & $329(17)$ & 9.788 & & & \\
\hline \multicolumn{6}{|c|}{ TP53 mutation } \\
\hline Wild-type & $721(88)$ & 8.132 & \multirow[t]{2}{*}{-7.47} & \multirow[t]{2}{*}{$1.2 \times 10^{-11}$} & \multirow[t]{2}{*}{$<0.0001$} \\
\hline Mutation & $99(12)$ & 9.148 & & & \\
\hline
\end{tabular}

ER oestrogen receptor, $P g R$ progesterone receptor, $H E R 2$ human epidermal growth factor receptor 2

$p$ value in bold in these tables means statistically significant associations

subtype, while SCL7A5 copy number loss was mainly observed in the luminal A subtype $(p<0.001$, Table 2$)$.

\section{SLC7A5 expression and other associated markers}

Correlation between SLC7A5 mRNA and associated genes was investigated in the METABRIC dataset (Table 5). The genes were selected based on previous publications, and were either regulatory genes or others that share or support the SLC7A5 biological function, which focused mainly on glutamine transport and glutamine metabolism $[2,5,15,37-41]$. There was positive correlation between SLC7A5 mRNA expression and the expression of regulatory genes, several amino acid transporters and genes involved in the glutamine-proline regulatory axis. There was a positive relationship between SLC7A5 and MYC, mTOR and ATF4 $(p<0.001)$ and the positive relationship between MYC, HIF2A and SLC7A5 was only observed in luminal B tumours ( $p=0.01$ and $p<0.001$, respectively).

High SLC7A5 mRNA expression was specifically associated with the enzymes involved with conversion of glutamine (Gln) to proline, where PYCR1 and ALDH18A1 showed a positive relationship with SLC7A5 in almost all subtypes $(p<0.02)$.

The majority of glutamine transporters were significantly associated with SLC7A5 expression primarily in triple negative tumours and to a lesser extent luminal and HER2+ subtypes. SLC7A5 was significantly correlated with SLC1A5 in all subtypes $(p<0.02)$.

TP53 mutations were also highly prevalent in breast tumours where there was high SLC7A5 mRNA expression ( $p$ $<0.001$, Tables 3 and 4). Moreover, high SLC7A5 protein was positively associated with high p53 protein $(p<0.001)$.

SLC7A5 protein expression was significantly expressed in breast tumours with high Ki67, and the upstream effector MYC $(p<0.001$, Table 6). SLC1A5, GLS, PYCR1 and PIK3CA were significantly expressed in breast tumours with high expression of SLC7A5 ( $p$ $<0.001$ ), while the low expression of SLC7A5 was associated with high levels of p-mTORC1 $(p<0.001)$ (Table 6).

\section{SLC7A5 expression and patient outcome}

Both high SLC7A5 mRNA $(p<0.001)$ (Fig. 4a) and protein $(p<0.001)$ expression were associated with poor BCSS in the discovery and validation sets (Fig. 5a, b). This association was anticipated as the cutoff was based on the prediction of BCSS.

While SLC7A5 mRNA expression was not predictive of BCSS in any specific molecular class (Fig. 4be), high expression of SLC7A5 protein was only predictive of shorter BCSS in ER+ high proliferation $(p=$ 0.007, Fig. 5d) and HER2+ tumours ( $p=0.03$, Fig. 5f). 
Table 5 Correlation of SLC7A5 expression with the expression of other related genes in the Molecular Taxonomy of Breast Cancer International Consortium (METABRIC) data

\begin{tabular}{|c|c|c|c|c|c|c|c|c|c|c|}
\hline & \multicolumn{10}{|c|}{ SLC7A5 mRNA expression } \\
\hline & \multicolumn{2}{|c|}{ All cases $(n=1980)$} & \multicolumn{2}{|c|}{ Luminal A $(n=368)$} & \multicolumn{2}{|c|}{ Luminal B $(n=367)$} & \multicolumn{2}{|c|}{ HER2 $+(n=110)$} & \multicolumn{2}{|c|}{ Triple negative $(n=150)$} \\
\hline & \multicolumn{3}{|c|}{$\overline{\text { Correlation Coefficient ( } p \text { value) }}$} & \multicolumn{3}{|c|}{ Adjusted $p$ value } & & & & \\
\hline \multicolumn{11}{|c|}{ Regulatory and other associated genes } \\
\hline MYC & $\left.\begin{array}{l}0.133 \\
-9\end{array}\right)$ & $<0.0001$ & $0.012(0.752)$ & 4.145 & $0.155(0.001)$ & 0.019 & $0.066(0.310)$ & 4.650 & $0.103(0.062)$ & 0.434 \\
\hline mTOR & $0.085(0.0001)$ & 0.001 & $-0.005(0.904)$ & 1.824 & $0.088(0.052)$ & 0.728 & $\begin{array}{l}-0.023 \\
(0.723)\end{array}$ & 5.784 & $0.067(0.226)$ & 1.130 \\
\hline VEGFA & $\underset{-59)}{0.352}(6.4 \times 10$ & $<0.0001$ & $\begin{array}{l}0.166 \\
(0.000008)\end{array}$ & 0.0002 & $\left.\begin{array}{l}0.260(5.3 \times 10 \\
-9\end{array}\right)$ & $<0.0001$ & $\begin{array}{l}0.269 \\
(0.00002)\end{array}$ & 0.0005 & $0.244(0.000008)$ & 0.0002 \\
\hline HIF2A & $-0.050(0.028)$ & 0.168 & $-0.023(0.536)$ & 4.896 & $0.215(0.000002)$ & $<0.0001$ & $0.112(0.083)$ & 1.328 & $\begin{array}{l}-0.282(1.8 \times 10 \\
-7)\end{array}$ & $<0.0001$ \\
\hline ATF4 & $\begin{array}{l}0.159 \\
-12)\end{array}(1.0 \times 10$ & $<0.0001$ & $-0.029(0.433)$ & 5.100 & $0.057(0.208)$ & 2.080 & $0.143(0.026)$ & 0.468 & $0.108(0.050)$ & 0.450 \\
\hline \multicolumn{11}{|c|}{ Glutamine-proline regulatory axis } \\
\hline GLS & $0.048(0.032)$ & 0.192 & $0.008(0.829)$ & 3.428 & $0.055(0.222)$ & 1.998 & $\begin{array}{l}-0.006 \\
(0.927)\end{array}$ & 4.635 & $-0.115(0.038)$ & 0.456 \\
\hline ALDH4A1 & $-0.053(0.019)$ & 0.133 & $0.018(0.638)$ & 4.512 & $0.063(0.163)$ & 1.793 & $\begin{array}{l}-0.028 \\
(0.663)\end{array}$ & 5.967 & $-0.134(0.015)$ & 0.225 \\
\hline PRODH & $0.004(0.858)$ & 1.716 & $-0.034(0.369)$ & 4.763 & $-0.032(0.483)$ & 2.415 & $0.037(0.573)$ & 5.73 & $0.030(0.582)$ & 1.746 \\
\hline PYCR1 & $\left.\frac{0.32}{-50}\right)(1.5 \times 10$ & $<0.0001$ & $0.143(0.0001)$ & 0.001 & $\left.\begin{array}{l}0.253 \\
-8\end{array}\right)$ & $<0.0001$ & $0.210(0.001)$ & 0.024 & $\left.\begin{array}{l}0.303 \\
-8\end{array}\right)$ & $<0.0001$ \\
\hline ALDH18A1 & $\begin{array}{l}0.222(1.6 \times 10 \\
-23)\end{array}$ & $<0.0001$ & $0.151(0.00004)$ & 0.0008 & $0.144(0.001)$ & 0.018 & $0.168(0.009)$ & 0.180 & $\begin{array}{l}0.356 \\
-11)\end{array}$ & $<0.0001$ \\
\hline GLUL & $\begin{array}{l}-0.18(3.3 \times 10 \\
-16)\end{array}$ & $<0.0001$ & $0.134(0.0003)$ & 0.005 & $0.008(0.863)$ & 1.726 & $\begin{array}{l}-0.001 \\
(0.991)\end{array}$ & 1.982 & $-0.122(0.028)$ & 0.392 \\
\hline GLUD1 & $\begin{array}{l}-0.38(4.3 \times 10 \\
-69\end{array}$ & $<0.0001$ & $\begin{array}{l}-0.161 \\
(0.00001)\end{array}$ & 0.0002 & $\begin{array}{l}-0.237(1.1 \times 10 \\
-7)\end{array}$ & $<0.0001$ & $\begin{array}{l}-0.148 \\
(0.022)\end{array}$ & 0.418 & $-0.112(0.042)$ & 0.420 \\
\hline \multicolumn{11}{|c|}{ Glutamine/glutamate transporters } \\
\hline SLC1A5 & $\left.\frac{0.29}{-41}\right)(4.5 \times 10$ & $<0.0001$ & $\begin{array}{l}0.170 \\
(0.000005)\end{array}$ & 0.0001 & $0.150(0.001)$ & 0.017 & $0.208(0.001)$ & 0.023 & $0.25(0.000002)$ & $<0.0001$ \\
\hline SLC3A2 & $\frac{0.17}{-14}(1.1 \times 10$ & $<0.0001$ & $0.067(0.072)$ & 3.780 & $0.193(0.00001)$ & 0.0002 & $0.184(0.004)$ & 0.084 & $0.158(0.004)$ & 0.064 \\
\hline SLC6A19 & $0.004(0.869)$ & 1.738 & $0.041(0.273)$ & 4.428 & $-0.008(0.859)$ & 2.577 & $0.047(0.473)$ & 5.676 & $-0.103(0.061)$ & 0.488 \\
\hline SLC7A6 & $\underset{-62)}{0.362}(2.7 \times 10$ & $<0.0001$ & $\begin{array}{l}0.254 \\
-12)\end{array}$ & $<0.0001$ & $\left.{ }_{14}^{0.33}\right)\left(2.0 \times 10^{-}\right.$ & $<0.0001$ & $\begin{array}{l}0.284 \\
(0.000008)\end{array}$ & 0.0002 & $0.071(0.201)$ & 1.206 \\
\hline SLC7A7 & $\underset{-19}{0.19}(4.6 \times 10$ & $<0.0001$ & $0.007(0.857)$ & 2.712 & $0.085(0.061)$ & 0.793 & $0.041(0.530)$ & 5.830 & $-0.22(0.00005)$ & 0.0001 \\
\hline SLC7A8 & $\begin{array}{l}-0.42(1.1 \times 10 \\
-88)\end{array}$ & $<0.0001$ & $-0.115(0.002)$ & 0.034 & $-0.103(0.022)$ & 0.352 & $\begin{array}{l}-0.203 \\
(0.002)\end{array}$ & 0.044 & $\begin{array}{l}-0.40\left(3.9 \times 10^{-}\right. \\
14)\end{array}$ & $<0.0001$ \\
\hline SLC7A9 & $-0.068(0.002)$ & 0.01 & $0.025(0.510)$ & 4.82 & $0.044(0.333)$ & 2.331 & $\begin{array}{l}-0.123 \\
(0.056)\end{array}$ & 0.952 & $\underset{-7}{0.283}(1.8 \times 10$ & $<0.0001$ \\
\hline SLC38A1 & $\begin{array}{l}-0.10 \\
(0.000003)\end{array}$ & $<0.0001$ & $-0.041(0.270)$ & 3.549 & $0.039(0.391)$ & 2.346 & $0.053(0.413)$ & 5.369 & $0.113(0.041)$ & 0.451 \\
\hline SLC38A2 & $-0.055(0.015)$ & 0.120 & $-0.074(0.048)$ & 1.05 & $-0.103(0.022)$ & 0.330 & $0.007(0.917)$ & 5.502 & $-0.119(0.032)$ & 0.416 \\
\hline SLC38A3 & & $<0.0001$ & $0.140(0.0001)$ & 0.002 & $0.046(0.311)$ & 2.488 & $0.003(0.958)$ & 2.874 & $0.196(0.0003)$ & 0.005 \\
\hline
\end{tabular}


Table 5 Correlation of SLC7A5 expression with the expression of other related genes in the Molecular Taxonomy of Breast Cancer International Consortium (METABRIC) data (Continued)

\begin{tabular}{|c|c|c|c|c|c|c|c|c|c|c|}
\hline & \multicolumn{10}{|c|}{ SLC7A5 mRNA expression } \\
\hline & \multicolumn{2}{|c|}{$\overline{\text { All cases }(n=1980)}$} & \multicolumn{2}{|c|}{ Luminal A $(n=368)$} & \multicolumn{2}{|c|}{ Luminal $\mathrm{B}(n=367)$} & \multicolumn{2}{|c|}{ HER2+ $(n=110)$} & \multicolumn{2}{|c|}{ Triple negative $(n=150)$} \\
\hline & \multicolumn{3}{|c|}{$\overline{\text { Correlation Coefficient ( } p \text { value) }}$} & \multicolumn{3}{|c|}{ Adjusted $p$ value } & & & & \\
\hline & $\begin{array}{l}0.18(8.3 \times 10 \\
-17)\end{array}$ & & & & & & & & & \\
\hline SLC38A5 & $0.011(0.627)$ & 2.574 & $-0.069(0.066)$ & 1.08 & $-0.077(0.090)$ & 1.080 & $\begin{array}{l}-0.017 \\
(0.793)\end{array}$ & 5.551 & $-0.017(0.757)$ & 1.514 \\
\hline SLC38A7 & $\left.\begin{array}{l}0.306 \\
-44\end{array}\right)$ & $<0.0001$ & $\begin{array}{l}0.270(2.0 \times 10 \\
-13)\end{array}$ & $<0.0001$ & $\underset{-13)}{0.32}(1.2 \times 10$ & $<0.0001$ & $0.064(0.324)$ & 4.536 & $0.177(0.001)$ & 0.017 \\
\hline SLC38A8 & $0.023(0.312)$ & 1.560 & $-0.019(0.612)$ & 4.466 & $0.011(0.801)$ & 3.204 & $\begin{array}{l}-0.006 \\
(0.930)\end{array}$ & 3.720 & $-0.039(0.482)$ & 1.928 \\
\hline
\end{tabular}

$p$ value in bold in these tables means statistically significant associations

There was no association between SLC7A5 protein and outcome in ER+ low proliferation (Fig. 5c) or in TNBC (Fig. 5e). In multivariate Cox regression analysis, SLC7A5 mRNA was a predictor of shorter BCSS independent of tumour size, grade or lymph node stage $(p=0.006$, Additional file 5: Table S3) but not in any specific subtype. However, SLC7A5 protein was significant only in the ER+ high-proliferation tumours $(p=0.02$, Table 7$)$ and not in any other subtypes (data not shown).

Likewise, high SLC7A5 protein expression was associated with shorter distant metastases-free survival (DMFS) $(p<0.001$; Additional file 6: Figure S2A, B) within the ER+ high-proliferation class $(p=0.03$, Additional file 6: Figure S2D) but not in other subtypes (Additional file 6: Figure S2C, E, F). This association was identified in the discovery set and validated in the validation set. The relationship between high SLC7A5 mRNA expression and poor patient outcome in ER+ disease, but not ER- disease, was confirmed using Breast Cancer Gene-Expression Miner (Additional file 7: Figure S3A, B, C).

Table 6 Correlation between SLC7A5 protein expression and other biomarkers in the discovery set

\begin{tabular}{llll}
\hline \multicolumn{4}{l}{ SLC7A5 protein } \\
\hline Biomarker & Correlation coefficient & $p$ value & Adjusted $p$ value \\
\hline c-MYC & 0.164 & $8.2 \times 10^{-7}$ & $<\mathbf{0 . 0 0 0 1}$ \\
Ki67 & 0.311 & $1.1 \times 10^{-21}$ & $<\mathbf{0 . 0 0 0 1}$ \\
P-mTORC1 & -0.150 & 0.00001 & $<\mathbf{0 . 0 0 0 1}$ \\
PIK3CA & 0.190 & $3.4 \times 10^{-7}$ & $<\mathbf{0 . 0 0 0 1}$ \\
SLC1A5 & 0.331 & $1.1 \times 10^{-25}$ & $<\mathbf{0 . 0 0 0 1}$ \\
GLUD1 & 0.053 & 0.09 & 0.180 \\
GLS & 0.371 & $2.2 \times 10^{-30}$ & $<\mathbf{0 . 0 0 0 1}$ \\
PYCR1 & 0.283 & $1.07 \times 10^{-16}$ & $<\mathbf{0 . 0 0 0 1}$
\end{tabular}

$p$ value in bold in these tables means statistically significant associations

\section{Discussion}

Breast cancer is a heterogeneous disease with various subtypes [42] differing in terms of morphology, molecular and biological profiles, response to therapy and clinical behaviour. In addition, different subtypes exhibit disparity in their metabolic pathways and their nutritional needs. The most common form of $\mathrm{BC}(\sim 55-80 \%)$ is the ER+/luminal tumour $[43,44]$, and tumours that belong to this class are also variable in terms of recurrence, mortality rates and disease prognosis [43]. Therefore, understanding the biology of $\mathrm{BC}$ and exploring the metabolic pathways could help to identify potential novel therapeutic targets.

Cancer cells must alter their metabolism in order to satisfy the demands of necessary energy and cellular building blocks. It is widely known that amino acid transport systems play a principal role in sustaining the proliferation of cancer cells by supplying the required amino acids for protein synthesis and by activation of nutrient signalling through the mTORC1 complex. This study has revealed for the first time that SLC7A5 is a key amino acid transporter in the more aggressive and highly proliferative ER+ tumours.

$S L C 7 A 5$ is located in 16q24.2. This study showed that SLC7A5 deletion, but not amplification, was significantly correlated with all the annotated genes located in the same chromosomal region, indicating that the deletion was not locus-specific. Interestingly, Ecadherin (CDH1), which was located in 16q22.1, was also implicated. It is widely known that most lobular tumours harbour loss of heterozygosity (LOH) at chromosome 16 and are missing the wild type $C D H 1$ allele [45]. In this study, approximately $40 \%$ of METABRIC cases with SLC7A5 loss were associated with invasive lobular histology. In addition, SLC7A5 protein expression in lobular carcinoma has a relatively lower mean rank value compared to the other histological subtypes, confirming that deletions involve large segments of q16, which can reflect the BC phenotype. 

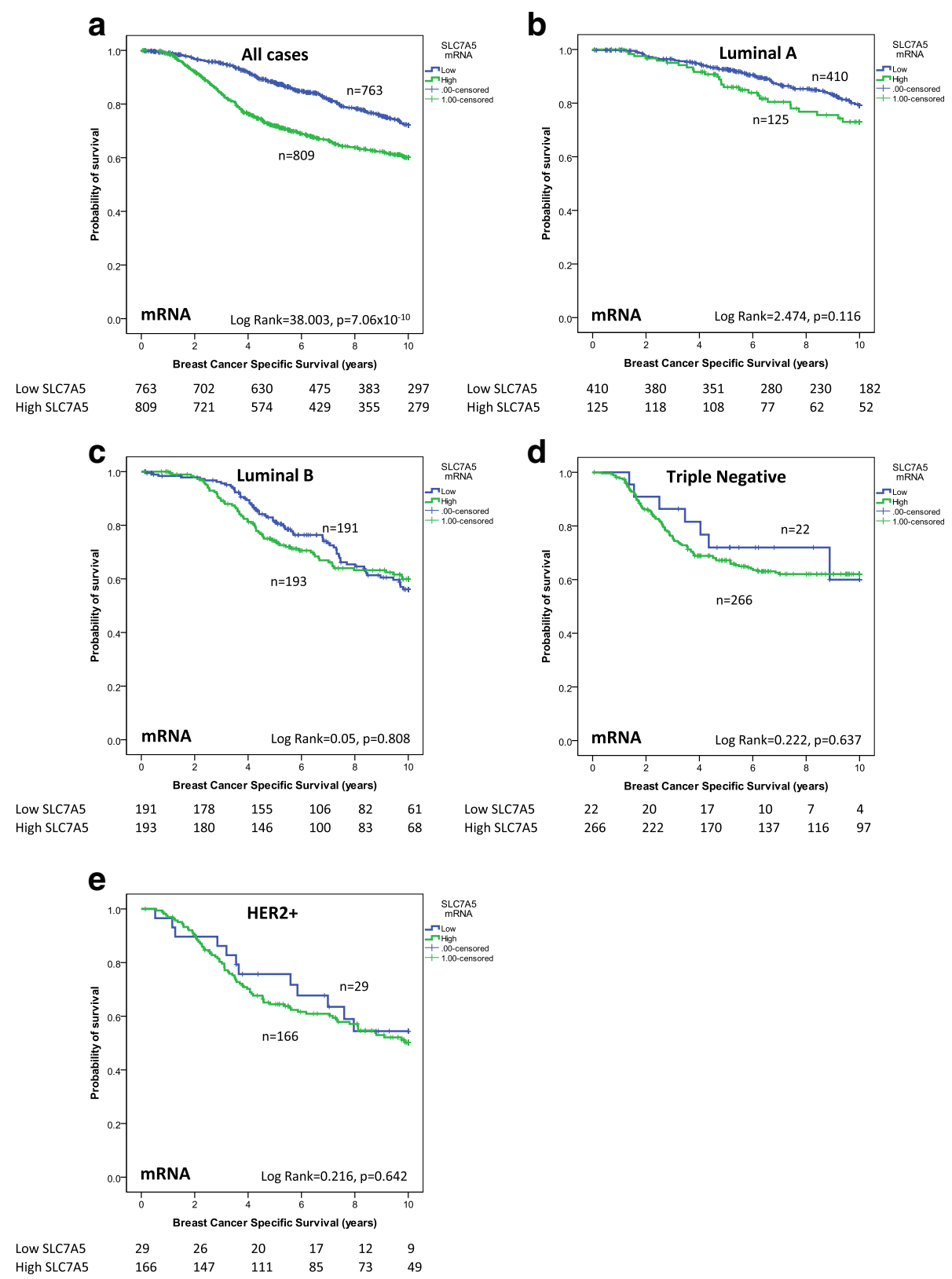

Fig. 4 SLC7A5 mRNA and breast cancer patient outcome. a SLC7A5 vs breast-cancer-specific survival (BCSS) in all cases. b SLC7A5 vs BCSS in luminal A tumours. c SLC7A5 vs BCSS in luminal B tumours. d SLC7A5 vs BCSS in triple negative tumours. e SLC7A5 vs BCSS in human epidermal growth factor receptor 2 (HER2+) tumours

SLC7A5 is widely expressed in many human cancers and various cancer cell lines [46]. The current study included two large discovery and validation cohorts to confirm the significant association between the high SLC7A5 protein expression and the poor prognostic clinico-pathological parameters, including larger tumour size, higher grade and poor NPI. Furthermore, high SLC7A5 expression was significantly associated with higher expression of the proliferative marker (Ki67). This supports the results of previous studies which demonstrated that these two biomarkers are significantly correlated in tongue cancer [47], neuroendocrine carcinoma of the lung [48], thymic carcinoma [49] and breast cancer [50], indicating that SLC7A5 is critical for proliferation in cancer cells.

With respect to the breast cancer ER+ subtypes, SLC7A5 expression was lower in ER+ tumours that have low proliferation (luminal A subtype) compared with the highly proliferative $\mathrm{ER}+$ (luminal B) malignancies, and it was primarily associated with poor patient outcome and 

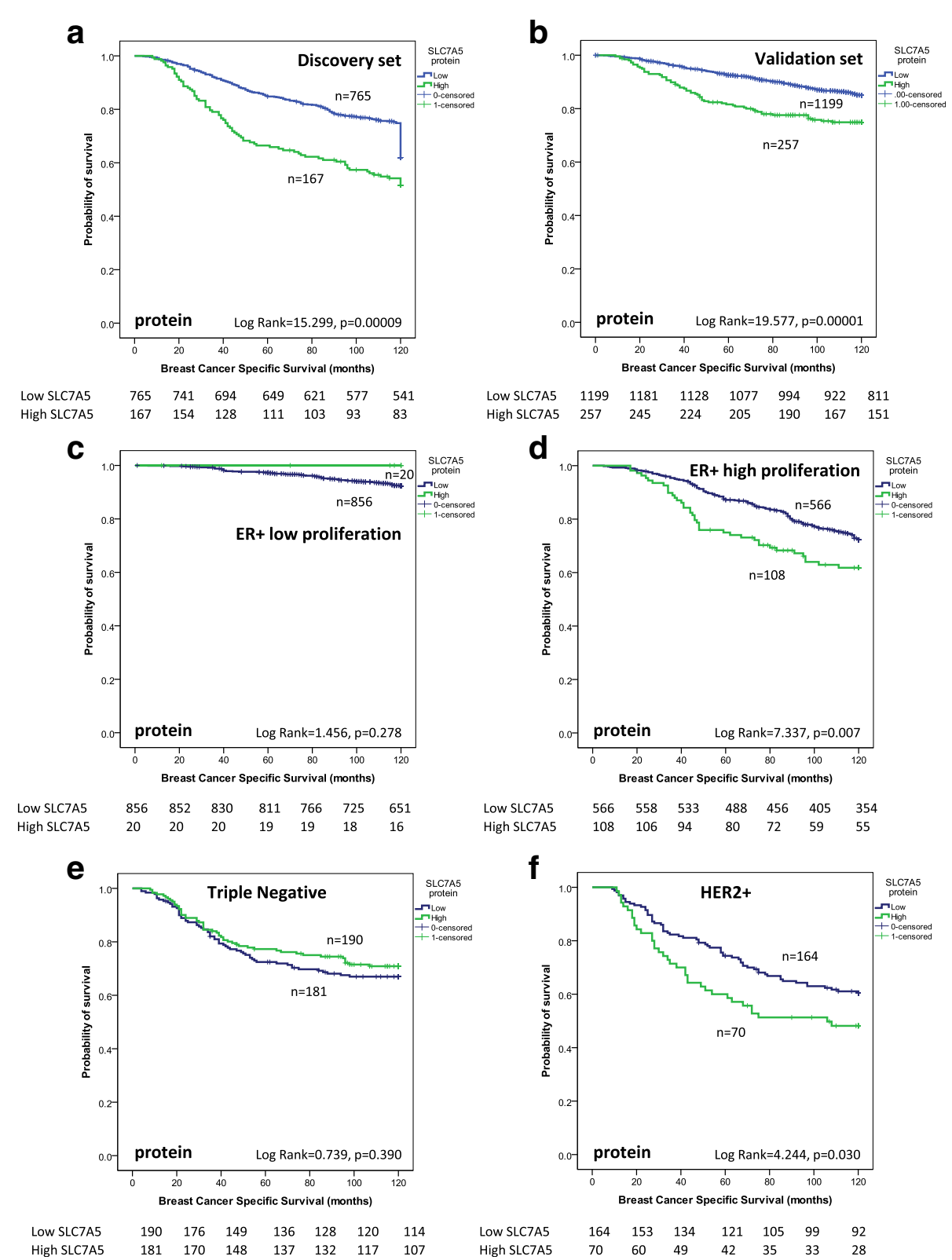

Fig. 5 SLC7A5 and breast cancer patient outcome. a SLC7A5 vs breast-cancer-specific survival (BCSS) in all discovery set cases. b SLC7A5 vs BCSS in all validation set cases. c SLC7A5 vs BCSS in oestrogen receptor (ER) + low proliferation tumours in the combined discovery and validation cases. d SLC7A5 vs BCSS in ER + high proliferation tumours in the combined discovery and validation cases. e SLC7A5 vs BCSS of triple negative tumours in the combined discovery and validation cases. $\mathbf{f}$ SLC7A5 vs BCSS human epidermal growth factor receptor 2 (HER2)+ tumours in the combined discovery and validation cases

shorter DMFS in the latter class only. This is most likely due to their heavier energy and nutrient requirements for cell survival, proliferation and metastasis. This was anticipated, as it has been shown that over expression of SLC7A5 is actively involved in the proliferation of vascular smooth muscle cells [51] and it is co-expressed with vascular endothelial growth factor (VEGF) in the primary and metastatic sites of many cancers [37], which may be implicated for the metastatic process. In this study the most significant positive correlation between mRNA expression of SLC7A5 and VEGFA was identified in the luminal B subtype. In this regard, Bartlett et al. included SLC7A5 as a part of the five-gene Mammostrat ${ }^{\circ}$ immunohistochemistry panel, where the higher expression is used to predict recurrence-free survival (RFS), DMFS and overall survival (OS) in ER+ breast cancer during endocrine therapy [52]. However, they did not consider the different molecular subtypes of BC. 
Table 7 SLC7A5 protein expression and patient outcome in the combined discovery and validation sets in all cases and in ERpositive high proliferation tumours

\begin{tabular}{|c|c|c|c|c|c|c|}
\hline \multicolumn{7}{|l|}{ SLC7A5 protein } \\
\hline \multirow[b]{2}{*}{ Parameter } & \multicolumn{3}{|l|}{ All cases } & \multicolumn{3}{|l|}{ ER+ high proliferation } \\
\hline & Hazard ratio $(95 \% \mathrm{Cl})$ & $p$ value & Adjusted $p$ value & Hazard ratio $(95 \% \mathrm{Cl})$ & $p$ value & Adjusted $p$ value \\
\hline SLC7A5 & $1.001(1.000-1.003)$ & 0.063 & 0.126 & $1.004(1.001-1.006)$ & 0.006 & 0.024 \\
\hline Lymph node stage & $2.060(1.813-2.341)$ & $1.7 \times 10^{-28}$ & $<0.0001$ & $1.756(1.427-2.161)$ & $1.04 \times 10^{-7}$ & $<0.0001$ \\
\hline Size & $1.365(1.111-1.678)$ & 0.003 & 0.009 & $1.169(0.838-1.632)$ & 0.358 & 0.716 \\
\hline Grade & $2.454(2.023-2.977)$ & $1.8 \times 10^{-20}$ & $<0.0001$ & $1.756(1.154-2.672)$ & 0.009 & 0.027 \\
\hline
\end{tabular}

$p$ value in bold in these tables means statistically significant associations

SLC7A5 mRNA and protein was also highly expressed in TNBC and HER2+ BC, in concordance with Furuya et al. [50]. However, in these subtypes the significant association between SLC7A5 protein expression and patient outcome was only observed in the HER2+ tumours. Among all BC subtypes, SLC7A5 protein expression was an independent predictor of short BCSS in ER+ high-proliferation tumours only. In this regard, the larger sample of ER+ high-proliferation cases might reflect the stronger significance compared with the smaller sample of HER2+ and TNBC tumours. We therefore suggest that further confirmation in larger cohorts of HER2+ and TN tumours is warranted.

Previous studies have shown regulation of SLC7A5 by other proteins including the tumour oncogene Myc, which induces SLC7A5 $[4,5]$. In the current study, the relationship between SLC7A5 and other regulatory proteins in both mRNA and protein expression was investigated. A positive relationship was observed between SLC7A5 and Myc in both protein and mRNA levels, and this correlation remained significant only in luminal B subtype, when different subtypes were investigated. ATF4-dependent transcripts also encode for SLC7A5 upon amino acid deprivation [39] and in this study there was positive correlation between ATF4 and SLC7A5 gene expression, in line with expectations. A previous study showed that activation of the HIF $2 \alpha$ pathway increases mTORC1 activity by upregulating expression of the amino acid carrier SLC7A5 [38] and the current study confirmed the positive correlation between HIF2 $\alpha$ and SLC7A5, which was only observed in luminal B tumours. SLC7A5 functions by importing essential amino acids to cancer cells and research has detailed the role of amino acids, particularly leucine, in activating mTORC1, which in turn controls protein translation and cell proliferation, and prevents apoptosis in malignant cells [2,3]. This study showed positive correlation between SLC7A5 and mTOR at the mRNA level. However, there were conflicting results in the analysis of protein levels of SLC7A5, whereby high SLC7A5 expression was associated with lower expression of the mTORC1 phosphorylated at ser (2448), which was included in this study.
This was unsurprising as Cheng et al. confirmed that phosphorylation of mTORC1 at ser (2448), which is stimulated by growth factors, was mutually exclusive with mTORC1 phosphorylated at thr (2446), which is regulated by amino acids [53]. These observations may explain why SLC7A5 over expression is primarily associated with poor outcome only in the high proliferation ER+ tumours.

This study further investigated the association of SLC7A5 expression with other glutamine transporters, in which some variability in the expression of amino acid transporters across molecular subtypes was observed. For example, the TN subtype was the main class associated with the transporters required for glutamine influx, perhaps because it depends on delivery of glutamine instead of synthesis. In contrast, positive correlation between SLC7A5 and the glutamine synthase enzyme GLUL was observed in luminal A tumours, suggesting that this subtype might rely on glutamine neosynthesis rather than uptake. SLC1A5 functionally couples with SLC7A5 to allow the cellular influx and efflux of glutamine, as SLC1A5 mediates uptake of glutamine, while SLC7A5 uses intracellular glutamine concentrations to adjust the essential amino acid cytoplasmic pool for metabolic demands and signalling to mTORC1 [15]. Here we observed that SLC7A5 and SLC1A5 are positively correlated in all the $\mathrm{BC}$ subtypes.

Previous studies have raised awareness and revealed the importance of the proline-glutamine (Pro-Gln) regulatory axis in BC. SLC7A5 appears to have a pivotal role in this regulatory axis, as its expression was highly associated with the enzymes that mediate glutamate degradation to form the amino acid proline, which has been shown to play a role in assisting tumour growth by different mechanisms [54].

Blocking of SLC7A5 using its inhibitor, 2aminobicyclo-(2,2,1)-heptane-2-carboxylic acid (BCH), efficiently decreased colony formation of MDA-MB-231 TNBC cells [55]. Even though the consequences of blocking SLC7A5 in the highly proliferative ER+ tumours remain undetermined, this study suggests that SLC7A5 can potentially be used as a therapeutic target for luminal B BC. 


\section{Conclusion}

This study revealed and confirmed that the glutamine transporter SLC7A5 is associated with poor prognostic characteristics and poor survival outcome. Over expression of SLC7A5 appears to play a role in the proliferation and progression of the aggressive ER+ subtype of breast cancer, thus it could act as a potential therapeutic target. Functional assessment is necessary to reveal the specific role played by this amino acid transporter in the highly proliferative subclass and HER2+ BC.

\section{Additional files}

Additional file 1: Table S1. Clinicopathological parameters of the METABRIC and Nottingham discovery and validation series. (DOCX $16 \mathrm{~kb}$ )

Additional file 2: Figure S4. SLC7A5 mRNA expression, in the TCGA data, and its association with copy number alteration (A), staging system (B), ER status (C), PR status (D) and HER2 (E) status. (PPTX $176 \mathrm{~kb}$ )

Additional file 3: Table S2. List of genes with copy number loss that was significantly associated with SLC7A5 deletion in the METABRIC and TCGA data. (DOCX 16 kb)

Additional file 4: Figure S1. SLC7A5 gene expression and its association, using Breast Cancer Gene-Expression Miner v4.0, with: tumour grade (A), NPI (B), ER status (C), PR status (D), HER2 status (E), Triple Negative status (F)and PAM50 subtypes (G). (PPTX $117 \mathrm{~kb}$ )

Additional file 5: Table S3. SLC7A5 mRNA and patient outcome. (DOCX $14 \mathrm{~kb}$ )

Additional file 6: Figure S2. SLC7A5 vs DMFS in all cases in the discovery set (A), all cases in the validation set (B), ER + low proliferation tumours in the combined discovery and validation set cases (C), ER + high proliferation tumours in the combined discovery and validation set cases (D), triple negative tumours in the combined discovery and validation set cases (E) and HER2+ tumours in the combined discovery and validation set (F). (PPTX $407 \mathrm{~kb}$ )

Additional file 7: Figure S3. SLC7A5 mRNA and breast cancer patient outcome using Breast Cancer Gene-Expression Miner in unselected cases $(\mathrm{K}), \mathrm{ER}+$ disease $(\mathrm{L})$ and ER- disease (M). (PPTX $80 \mathrm{~kb}$ )

\section{Abbreviations}

BC: Breast cancer; BCH: 2-Aminobicyclo-(2,2,1)-heptane-2-carboxylic acid; BCSS: Breast cancer specific survival; $\mathrm{CDH} 1$ : E-cadherin; $\mathrm{CISH}$ : Chromogenic in situ hybridisation; CK: Cytokeratin; CNA: Copy number aberration; CNV: Copy number variation; DM: Distant metastasis; DMFS: Distant metastasis-free survival; ECL: Enhanced chemiluminescence; ER: Oestrogen receptor; GIn: Glutamine; HER2: Human epidermal growth factor receptor 2; kDa: KiloDalton; LN: Lymph node; LOH: Loss of heterozygosity; METABRIC: Molecular Taxonomy of Breast Cancer International Consortium; mTORC1: Mammalian target of rapamycin complex1; NPI: Nottingham Prognostic Index; PAM50: Prediction analysis of microarray 50;

PBS: Phosphate-buffered saline; PgR: Progesterone receptor; Pro: Proline; SNP: Single nucleotide polymorphism; TBS: Tris-buffered saline; TCGA: The Cancer Genome Atlas; TMA: Tissue microarray; TN: Triple negative;

TNBC: Triple negative breast cancer; VEGF: Vascular endothelial growth factor

\section{Acknowledgements}

We thank the Nottingham Health Science Biobank and Breast Cancer Now Tissue Bank for the provision of tissue samples.

\section{Funding}

Not applicable.

\section{Availability of data and materials}

The datasets generated during the current study are available from the corresponding author on reasonable request.

\section{Authors' contributions}

RE contributed to writing, IHC staining, scoring, data analysis and interpretation; MLC contributed to writing and reviewing the manuscript; IM helped in scoring and double scoring; MDR and CCN helped in the laboratory work; IOE and EAR contributed to writing and reviewing the manuscript; ARG contributed to study design, data analysis and interpretation and writing and reviewing the manuscript. All authors read and approved the final manuscript.

\section{Ethics approval and consent to participate}

This study was approved by the Nottingham Research Ethics Committee 2 under the title "Development of a molecular genetic classification of breast cancer".

Consent for publication

Not applicable.

\section{Competing interests}

The authors declare that they have no competing interests.

\section{Publisher's Note}

Springer Nature remains neutral with regard to jurisdictional claims in published maps and institutional affiliations.

\section{Author details}

${ }^{1}$ Academic Pathology, Division of Cancer and Stem Cells, School of Medicine, University of Nottingham, Nottingham City Hospital, Hucknall Road, Nottingham NG5 1PB, UK. 'Breast Institute, Nottingham University Hospitals NHS Trust, Hucknall Road, Nottingham NG5 1PB, UK.

Received: 10 October 2017 Accepted: 26 February 2018

Published online: 22 March 2018

References

1. Hanahan D, Weinberg RA. Hallmarks of cancer: the next generation. Cell. 2011;144(5):646-74.

2. Bond P. Regulation of mTORC1 by growth factors, energy status, amino acids and mechanical stimuli at a glance. J Int Soc Sports Nutr. 2016;13:8.

3. Bar-Peled L, Sabatini DM. Regulation of mTORC1 by amino acids. Trends Cell Biol. 2014;24(7):400-6.

4. Gao P, Tchernyshyov I, Chang TC, Lee YS, Kita K, Ochi T, Zeller KI, De Marzo AM, Van Eyk JE, Mendell JT, et al. c-Myc suppression of miR-23a/b enhances mitochondrial glutaminase expression and glutamine metabolism. Nature. 2009:458(7239):762-5.

5. Hayashi $\mathrm{K}$, Jutabha P, Endou H, Anzai N. c-Myc is crucial for the expression of LAT1 in MIA Paca-2 human pancreatic cancer cells. Oncol Rep. 2012;28(3):862-6.

6. Reynolds MR, Lane AN, Robertson B, Kemp S, Liu Y, Hill BG, Dean DC, Clem $\mathrm{BF}$. Control of glutamine metabolism by the tumor suppressor Rb. Oncogene. 2014;33(5):556-66.

7. Kanai Y, Segawa H, Miyamoto K, Uchino H, Takeda E, Endou H. Expression cloning and characterization of a transporter for large neutral amino acids activated by the heavy chain of 4F2 antigen (CD98). J Biol Chem. 1998; 273(37):23629-32

8. Jewell JL, Kim YC, Russell RC, Yu FX, Park HW, Plouffe SW, Tagliabracci VS, Guan KL. Metabolism. Differential regulation of mTORC1 by leucine and glutamine. Science (New York, NY). 2015;347(6218):194-8.

9. Kimball SR. Regulation of translation initiation by amino acids in eukaryotic cells. Prog Mol Subcell Biol. 2001;26:155-84.

10. Bonfils G, Jaquenoud M, Bontron S, Ostrowicz C, Ungermann C, De Virgilio C. Leucyl-tRNA synthetase controls TORC1 via the EGO complex. Mol Cell. 2012:46(1):105-10.

11. Yanagida O, Kanai Y, Chairoungdua A, Kim DK, Segawa H, Nii T, Cha SH, Matsuo H, Fukushima J, Fukasawa Y, et al. Human L-type amino acid transporter 1 (LAT1): characterization of function and expression in tumor cell lines. Biochim Biophys Acta. 2001;1514(2):291-302.

12. Kobayashi H, Ishii $Y$, Takayama T. Expression of L-type amino acid transporter 1 (LAT1) in esophageal carcinoma. J Surg Oncol. 2005;90(4):233-8. 
13. Yoon JH, Kim IJ, Kim H, Kim HJ, Jeong MJ, Ahn SG, Kim SA, Lee CH, Choi BK, Kim JK, et al. Amino acid transport system $L$ is differently expressed in human normal oral keratinocytes and human oral cancer cells. Cancer Lett. 2005;222(2):237-45.

14. Nakanishi K, Matsuo H, Kanai $Y$, Endou H, Hiroi S, Tominaga S, Mukai M, Ikeda E, Ozeki Y, Aida S, et al. LAT1 expression in normal lung and in atypical adenomatous hyperplasia and adenocarcinoma of the lung. Virchows Arch. 2006;448(2):142-50.

15. Fuchs BC, Bode BP. Amino acid transporters ASCT2 and LAT1 in cancer: partners in crime? Semin Cancer Biol. 2005;15(4):254-66.

16. Curtis C, Shah SP, Chin SF, Turashvili G, Rueda OM, Dunning MJ, Speed D, Lynch AG, Samarajiwa S, Yuan Y, et al. The genomic and transcriptomic architecture of 2,000 breast tumours reveals novel subgroups. Nature. 2012; 486(7403):346-52.

17. Šidák Z. Rectangular confidence regions for the means of multivariate normal distributions. J Am Stat Assoc. 1967;62(318):626-33.

18. Ciriello G, Gatza ML, Beck AH, Wilkerson MD, Rhie SK, Pastore A, Zhang H, McLellan M, Yau C, Kandoth C, et al. Comprehensive molecular portraits of invasive lobular breast cancer. Cell. 2015;163(2):506-19.

19. Kao J, Salari K, Bocanegra M, Choi YL, Girard L, Gandhi J, Kwei KA, Hernandez-Boussard T, Wang P, Gazdar AF, et al. Molecular profiling of breast cancer cell lines defines relevant tumor models and provides a resource for cancer gene discovery. PLoS One. 2009;4(7):e6146.

20. Abd El-Rehim DM, Ball G, Pinder SE, Rakha E, Paish C, Robertson JF, Macmillan D, Blamey RW, Ellis IO. High-throughput protein expression analysis using tissue microarray technology of a large well-characterised series identifies biologically distinct classes of breast cancer confirming recent cDNA expression analyses. Int J Cancer. 2005;116(3):340-50.

21. McCarty KS Jr, McCarty KS Sr. Histochemical approaches to steroid receptor analyses. Semin Diagn Pathol. 1984;1(4):297-308.

22. Green AR, Aleskandarany MA, Agarwal D, Elsheikh S, Nolan CC, DiezRodriguez M, Macmillan RD, Ball GR, Caldas C, Madhusudan S, et al. MYC functions are specific in biological subtypes of breast cancer and confers resistance to endocrine therapy in luminal tumours. Br J Cancer. 2016; 114(8):917-28

23. Aleskandarany MA, Rakha EA, Ahmed MA, Powe DG, Ellis IO, Green AR. Clinicopathologic and molecular significance of phospho-Akt expression in early invasive breast cancer. Breast Cancer Res Treat. 2011;127(2):407-16.

24. Abdel-Fatah TM, Powe DG, Ball G, Lopez-Garcia MA, Habashy HO, Green AR, Reis-Filho JS, Ellis IO. Proposal for a modified grading system based on mitotic index and $\mathrm{Bcl} 2$ provides objective determination of clinical outcome for patients with breast cancer. J Pathol. 2010;222(4):388-99.

25. Elsheikh S, Green AR, Aleskandarany MA, Grainge M, Paish CE, Lambros MB, Reis-Filho JS, Ellis IO. CCND1 amplification and cyclin D1 expression in breast cancer and their relation with proteomic subgroups and patient outcome. Breast Cancer Res Treat. 2008;109(2):325-35.

26. Aleskandarany MA, Rakha EA, Macmillan RD, Powe DG, Ellis IO, Green AR. MIB1/Ki-67 labelling index can classify grade 2 breast cancer into two clinically distinct subgroups. Breast Cancer Res Treat. 2011:127(3):591-9.

27. Jerjees DA, Negm OH, Alabdullah ML, Mirza S, Alkaabi M, Hameed MR, Abduljabbar R, Muftah A, Nolan CC, Green AR, et al. The mammalian target of rapamycin complex 1 (mTORC1) in breast cancer: the impact of oestrogen receptor and HER2 pathways. Breast Cancer Res Treat. 2015;150(1):91-103.

28. Aleskandarany MA, Rakha EA, Ahmed MA, Powe DG, Paish EC, Macmillan RD, Ellis IO, Green AR. PIK3CA expression in invasive breast cancer: a biomarker of poor prognosis. Breast Cancer Res Treat. 2010;122(1):45-53.

29. Lancashire LJ, Powe DG, Reis-Filho JS, Rakha E, Lemetre C, Weigelt B, AbdelFatah TM, Green AR, Mukta R, Blamey R, et al. A validated gene expression profile for detecting clinical outcome in breast cancer using artificial neural networks. Breast Cancer Res Treat. 2010;120(1):83-93.

30. Green AR, Caracappa D, Benhasouna AA, Alshareeda A, Nolan CC, Macmillan RD, Madhusudan S, Ellis IO, Rakha EA. Biological and clinical significance of PARP1 protein expression in breast cancer. Breast Cancer Res Treat. 2015;149(2):353-62.

31. Elston CW, Ellis IO. Pathological prognostic factors in breast cancer. I. The value of histological grade in breast cancer: experience from a large study with long-term follow-up. C. W. Elston \& I. O. Ellis. Histopathology 1991; 19; 403-410. Histopathology. 2002;41(3a):151-2. discussion 152-153

32. Senkus E, Kyriakides S, Ohno S, Penault-Llorca F, Poortmans P, Rutgers E, Zackrisson S, Cardoso F. Primary breast cancer: ESMO clinical practice Guidelines for diagnosis, treatment and follow-up. Ann Oncol. 2015; 26(Suppl 5):v8-30.
33. Cerami E, Gao J, Dogrusoz U, Gross BE, Sumer SO, Aksoy BA, Jacobsen A, Byrne CJ, Heuer ML, Larsson E, et al. The cBio cancer genomics portal: an open platform for exploring multidimensional cancer genomics data. Cancer Discov. 2012;2(5):401-4

34. Gao J, Aksoy BA, Dogrusoz U, Dresdner G, Gross B, Sumer SO, Sun Y, Jacobsen $A$, Sinha $R$, Larsson $E$, et al. Integrative analysis of complex cancer genomics and clinical profiles using the cBioPortal. Sci Signal. 2013;6(269):pl1.

35. Huret JL, Ahmad M, Arsaban M, Bernheim A, Cigna J, Desangles F, Guignard JC, Jacquemot-Perbal MC, Labarussias M, Leberre V, et al. Atlas of genetics and cytogenetics in oncology and haematology in 2013. Nucleic Acids Res. 2013;41(Database issue):D920-4.

36. Parker JS, Mullins M, Cheang MC, Leung S, Voduc D, Vickery T, Davies S, Fauron $\mathrm{C}, \mathrm{He}$ X, Hu Z, et al. Supervised risk predictor of breast cancer based on intrinsic subtypes. J Clin Oncol. 2009;27(8):1160-7.

37. Kaira K, Oriuchi N, Imai H, Shimizu K, Yanagitani N, Sunaga N, Hisada T, Tanaka S, Ishizuka T, Kanai Y, et al. I-type amino acid transporter 1 and CD98 expression in primary and metastatic sites of human neoplasms. Cancer Sci. 2008;99(12):2380-6.

38. Elorza A, Soro-Arnaiz I, Melendez-Rodriguez F, Rodriguez-Vaello V, Marsboom G, de Carcer G, Acosta-lborra B, Albacete-Albacete L, Ordonez A, Serrano-Oviedo L, et al. HIF2alpha acts as an mTORC1 activator through the amino acid carrier SLC7A5. Mol Cell. 2012;48(5):681-91.

39. Adams CM. Role of the transcription factor ATF4 in the anabolic actions of insulin and the anti-anabolic actions of glucocorticoids. J Biol Chem. 2007; 282(23):16744-53.

40. Craze ML, Cheung H, Jewa N, Coimbra ND, Soria D, El-Ansari R, Aleskandarany MA, Cheng KW, Diez-Rodriguez M, Nolan CC. MYC regulation of glutamine-proline regulatory axis is key in luminal $\mathrm{B}$ breast cancer. $\mathrm{Br} \mathrm{J}$ Cancer. 2018;118(2):258-265.

41. El Ansari R, McIntyre A, Craze ML, Ellis IO, Rakha EA, Green AR. Altered glutamine metabolism in breast cancer; subtype dependencies and alternative adaptations. Histopathology. 2018;72(2):183-90.

42. Perou CM, Sorlie T, Eisen MB, van de Rijn M, Jeffrey SS, Rees CA, Pollack JR, Ross DT, Johnsen H, Akslen LA, et al. Molecular portraits of human breast tumours. Nature. 2000;406(6797):747-52.

43. Dawson SJ, Rueda OM, Aparicio S, Caldas C. A new genome-driven integrated classification of breast cancer and its implications. EMBO J. 2013;32(5):617-28.

44. Rakha EA, El-Sayed ME, Green AR, Paish EC, Powe DG, Gee J, Nicholson RI, Lee $\mathrm{AH}$, Robertson JF, Ellis IO. Biologic and clinical characteristics of breast cancer with single hormone receptor positive phenotype. J Clin Oncol. 2007:25(30):4772-8.

45. Berx G, Cleton-Jansen AM, Strumane K, de Leeuw WJ, Nollet F, van Roy F, Cornelisse C. E-cadherin is inactivated in a majority of invasive human lobular breast cancers by truncation mutations throughout its extracellular domain. Oncogene. 1996;13(9):1919-25

46. Wang Q, Holst J. L-type amino acid transport and cancer: targeting the mTORC1 pathway to inhibit neoplasia. Am J Cancer Res. 2015:5(4):1281-94.

47. Toyoda M, Kaira K, Ohshima Y, Ishioka NS, Shino M, Sakakura K, Takayasu Y, Takahashi K, Tominaga H, Oriuchi N, et al. Prognostic significance of aminoacid transporter expression (LAT1, ASCT2, and XCT) in surgically resected tongue cancer. Br J Cancer. 2014;110(10):2506-13.

48. Kaira K, Oriuchi N, Imai H, Shimizu K, Yanagitani N, Sunaga N, Hisada T, Kawashima O, lijima H, Ishizuka T, et al. Expression of L-type amino acid transporter 1 (LAT1) in neuroendocrine tumors of the lung. Pathol Res Pract. 2008;204(8):553-61.

49. Kaira K, Oriuchi N, Imai H, Shimizu K, Yanagitani N, Sunaga N, Hisada T, Ishizuka T, Kanai $Y$, Endou $H$, et al. L-type amino acid transporter 1 (LAT1) is frequently expressed in thymic carcinomas but is absent in thymomas. J Surg Oncol. 2009;99(7):433-8

50. Furuya M, Horiguchi J, Nakajima H, Kanai Y, Oyama T. Correlation of L-type amino acid transporter 1 and CD98 expression with triple negative breast cancer prognosis. Cancer Sci. 2012;103(2):382-9.

51. Liu XM, Reyna SV, Ensenat D, Peyton KJ, Wang H, Schafer Al, Durante W. Platelet-derived growth factor stimulates LAT1 gene expression in vascular smooth muscle: role in cell growth. FASEB J. 2004;18(6):768-70.

52. Bartlett JM, Thomas J, Ross DT, Seitz RS, Ring BZ, Beck RA, Pedersen HC, Munro A, Kunkler IH, Campbell FM, et al. Mammostrat as a tool to stratify breast cancer patients at risk of recurrence during endocrine therapy. Breast Cancer Res. 2010;12(4):R47. 
53. Cheng SW, Fryer LG, Carling D, Shepherd PR. Thr2446 is a novel mammalian target of rapamycin (mTOR) phosphorylation site regulated by nutrient status. J Biol Chem. 2004;279(16):15719-22.

54. Phang JM, Liu W, Hancock CN, Fischer JW. Proline metabolism and cancer: emerging links to glutamine and collagen. Curr Opin Clin Nutr Metab Care. 2015;18(1):71-7.

55. Liang Z, Cho HT, Williams L, Zhu A, Liang K, Huang K, Wu H, Jiang C, Hong $\mathrm{S}$, Crowe $\mathrm{R}$, et al. Potential biomarker of L-type amino acid transporter 1 in breast cancer progression. Nucl Med Mol Imaging. 2011;45(2):93-102.

Submit your next manuscript to BioMed Central and we will help you at every step:

- We accept pre-submission inquiries

- Our selector tool helps you to find the most relevant journal

- We provide round the clock customer support

- Convenient online submission

- Thorough peer review

- Inclusion in PubMed and all major indexing services

- Maximum visibility for your research

Submit your manuscript at www.biomedcentral.com/submit 